\title{
Dynamics in the Implementation of Adat Marriage Lawin Bali Community in Special Region of Yogyakarta
}

\author{
Iffah Nurhayati ${ }^{1}$, Setiati Widihastuti ${ }^{2}$, Puji Wulandari $^{3}$, Chandra Puspitasari $^{4}$ \\ Department of CivicEducation and Law, Yogyakarta State University, Indonesia \\ 1iffah_nurhayati@uny.ac.id, ${ }^{2}$ setiatiwidi@uny.ac.id, ${ }^{3}$ puji_wulandari@uny.ac.id, \\ ${ }^{4}$ chandradewi@uny.ac.id
}

\begin{abstract}
This article aims to explore further the shifting views of Balinese wanderers about customary marriage law. The approach used is a qualitative approach. The Balinese tradition which cannot be separated from Hinduism, is an ancestral custom that must be maintained by the Balinese people. One of them is to hold a traditional marriage to maintain the continuity of the patrilieal family system (kapurusa). The traditional marriage left a problem when the family did not have a son. To be more complicated, if the problem is experienced by the Balinese overseas people in a heterogeneous society and different cultural customs. As an actualization of the darma, the Balinese wanderers in DIY continue to obey the customary marriage law. Swadharma and swadikara only continued by kapurusa, reincarnation through kapurusa, is a reason to continue to obey adat marriage. Intermingling with the community in overseas areas and other factors has led to the dynamics of the views of the nomads and has become more open, such as accepting forms of marriage pada gelahang to accommodate change while maintaining the main principles of Balinese customary marriage law.
\end{abstract}

Keywords: Dynamics, Balinese Wanderers. Implementation, Balinese Traditional Marriage.

\section{Introduction}

Legal pluralism is a classic discussion in the context of developing the Indonesian legal system. In modern law characterized by unification, pluralism can be said to be an antithesis. According to SulistyowatiIrianto, legal pluralism in Indonesia refers to several things including the influence of customary law that cannot be ignored. Customary law is very tied to local cultural concepts, containing local wisdom and cultural knowledge that is needed to carry out the lives of the people concerned (SulityowatiIrianto, 2003: 80, 83).

The existence of customary law is maintained because factually customary law is still strongly binding to regulate life in some Indonesian people. One of the customary laws which is still firmly rooted is the Balinese Customary Law. The binding power of the Balinese (Hindu) community on customary law is partly due to the great influence of the (Hindu) religion on customary law in Bali.

The strong relationship between the teachings of Hinduism and Balinese customs is very evident in a series of marriage endorsement events held by Hindus in Bali. It can be suspected from awig-awigpakraman village (customary village regulations) which always requires the fulfillment of religious provisions in the implementation of marriage, marriage ratification through a series of religious ceremonies and witnessed by the traditional chief (Sudantra, 
2017: 161). The inseparability between adat and religion in the Balinese customary law community is due to the fact that the adat itself originates from religious teachings.

The Balinese are an ethnic group that adopts a patrilineal family system, descendants are tracked according to the father's line, which in Balinese is called purusa. Customary marriages are oriented towards maintaining the patrilineal family's continuity, so the purpose of marriage is related to the continuity of the family through purusawhich is propped up to boys. The presence of boys in the family to carry out self-reliance and swadharma in the family, for example, involves responsibility for children, parental care, rights and obligations to inheritance, responsibility for maintaining and sustaining family worship places (sanggah / merajan). Community responsibilities involve responsibilities as members of customary community members such as the banjar, pakramanvillages, subak and dadia (Adnyani, 2016: 762). Abandonment of the obligation (swadharma), commonly used as an excuse to abort someone's status as an heir.

In the traditional Balinese Hindu community there are several forms of marriage, including ordinary marriage and nyentana or nyeburinmarriage. A common marriage is a normal marriage or ngantenkeluar. In this case, the husband acts as a kapurusa (still living in his house), and the woman with the status of predana leaves the house and her family and becomes a member of her husband's family. The child born from this marriage follows his father's lineage, continues his swadharma and obtains swadikara from his father. Nganten out was chosen by the prospective couple from a family that has more than one child. In the sense of prospective husbands and prospective wives, each has more than one brother and sister (Hemmalini and Suhardi, 2015: 40-42).

Nyentana or ngantennyeburin marriages had to be done while in one family there were no sons. In nyentana marriage the man who is meawakluh (status as a woman or predana), leaves his family to enter the family of his wife who is meawakmuami (status as a man or purusa) and remains in his family after the marriage takes place. A woman who is married by squatting has the status of sentanarajeg, which continues her family lineage. The term Sentanarajeg is used to refer to a girl who is promoted as a sentanachild (equated as a boy). Furthermore, a child born from nyentana or nyeburin marriage will follow the lineage of his mother who has purusastatus. The form of nyentana marriage is usually chosen to avoid confusion, because all the children in the family have the opportunity to holdngantenkeluar (Hemmalini and Suhardi, 2015: 44-46). Seeing the importance of the meaning of marriage according to Balinese Customary Law, then maintaining the continuity of customary marriage law is an urgent matter.

The enforcement of customary law also cannot be separated from the supporting subjects, namely members of the customary law community; it is they who "decide" how the continuation of adat law. The subject's perspective on customary law becomes a determinant. On the other hand, this perspective is influenced by many factors that occur in one's life journey, including in social interactions. This will become increasingly apparent when members of indigenous peoples reside in other areas, such as migrating. "Wandering" is a social phenomenon that has occurred since the past, especially certain regions that have a tradition of wandering. Currently the term wandering has expanded its meaning, as the opinion of MoctharNaim (2012) who views this term as containing at least the basic elements of leaving home, of their own volition, for a long period of time or not, the purpose of finding life, seeking knowledge and seeking experience, and usually with the intention to return home.

In the modern era where social mobility is very high, migrating is a norm. Likewise, the Balinese who of course have diverse interests whose fulfillment are in other regions, so wandering is a choice that is undertaken. When talking about Balinese people wanderers, 
today many Balinese are scattered, becoming diaspora in other regions, including in the Special Region of Yogyakarta.

Bali wanderers activities in the Special Region of Yogyakarta is very possible for interadat communication. Unwittingly, Balinese migrants will be faced with new values that can influence their attitudes and mindsets. So it is not impossible that this Balinese migrant will position himself on the choice to remain faithful to maintain his customs or leave the customs of his ancestors and follow the customs in his new place. This could be a crucial threat to the preservation of Balinese customs brought from his hometown. Wandering will create cultural acculturation that allows the strengthening or even cultural change, which appears in the form of leaving the original customs. Acculturation can be interpreted as the inclusion of a value system, developmental order, role and personality factors as a contribution to how individuals accommodate when they meet each other (Padilla \& Perez, 2003).

The problem that has not been much studied from Bali migrants is about changing their value systems and social life. The length of time and distance to migrate is not impossible to diminish the closeness, obedience and loyalty of the Balinese diaspora to the customs of its ancestors. This study aims to illustrate the observance of Balinese migrants to customary marriage law, as well as the openness of overseas Balinese in the Special Region of Yogyakarta to changes in the implementation of Balinese traditional marriages.

\section{Research Methods}

This study aims to describe the observance of Balinese migrants to customary marriage law and the openness of Balinese migrants to changes in the implementation of traditional marriages in the Special Region of Yogyakarta. This study uses a qualitative approach to explore domains related to the main problem "The dynamics of the implementation of Balinese traditional marriages in the Special Region of Yogyakarta" which will then be elaborated into several focus research problems that are divided into several domains. The specifications of this study are descriptive, which illustrates the observance of Balinese migrants to customary marital law and the openness of Balinese migrants to changes in the implementation of traditional marriages in DIY. The research subjects is determined by snowball. The key informant was the Chairperson of Parisada Hindu Darma Indonesia, who knew exactly about Balinese customs, and had adequate knowledge about the members of his association. and have adequate knowledge about the members of the association. The initial informant will inform who the Balinese migrants who married (both their own and their children's marriages) after being overseas. The research data was collected through interviews and document studies. For validity of data at the stage of data collection activities, it is carried out by creating a good rapport with the informants; peer debriefing with peers, and crosschecking data sources and data collection methods. Inductive analysis is used to assess and analyze data that has focused on Bali observers 'adherence to customary marriage law and Bali migrants' openness to changes in the implementation of traditional marriages in DIY.

\section{Results And Discussion}

\subsection{Overview of the Balinese Community in the Special Region of Yogyakarta}


Hindu-Balinese society is rich in entrenched religious traditions and contains many arts and rituals. The majority of Balinese are Hindus. Hinduism in Bali is also called the Hindu Dharma or Tirtha (Holy Water Religion), has its own characteristics. With a more universal nature, free, and the acculturation of native Indonesian cultures makes Hinduism in Bali unique and different.

The Balinese are known as people who often migrate, although so far there have not been found sources that explain when they first came and settled in DIY. The Balinese overseas people continue to uphold the values of religion, culture and traditional traditions of Bali. One of them is by maintaining a horizontal relationship between humans and others. In DIY, they formed various communities as a medium of friendship to care for the values of Balinese culture abroad. Some communities that involve Balinese and Hindus, among others: a). Parisada Hindu Dharma Indonesia Special Region of Yogyakarta (PHDI DIY), b). Putra Bali Family (KPB) Purantara, c). The Hindu Dharma Indonesia Student Association of Yogyakarta Special Region (KMHD DIY), d). The Indonesian DIY Hindu Youth Association (Peradah), and various communities oftempekan.

In the formed community, non-formal activities are held to develop youngster's skills, character and cultural preservation. Jagatnata Temple, for example, held activities that were designed by Pura administrators, such as the "Sunday School" aimed at all generations of people. The material provided for these activities varies greatly about religion, customs and culture, including the traditional Balinese marriage. Through an introduction to Balinese culture and customs, particularly young people can understand their culture and customs, even though they are far from ancestral lands. In addition there are also activitiesPesantianwhich is organized by thetempekanfrom house to house in turns. The main activity of Pesantian is to study various matters relating to Balinese customs and culture and its problems, as well as social gathering and activities to strengthen member ties. This Pesantian activity becomes a facility for Balinese migrants in Jogja to help each other in carrying out various traditional Balinese ceremonies.

The lives of Balinese people who migrate also ruled by Balinese customs which cannot be separated from Hinduism. The practice of Hinduism is carried out through ethics, ethics and ceremonies. The Balinese wanderers have remained faithful in carrying out their customs and ceremonies. There are five types of Balinese traditional ceremonies in the form ofManusaYadnya Ceremony (such as in marriage and baby born), Dewa Yadnya Ceremony (Ceremonial Ceremony), PitraYadnya Ceremony (ceremony for people who have died) BhutaYadnya Ceremony (for creatures believed to exist ), and RsiYadnya Ceremony (ceremony or sacred sacrifice for people who are considered holy such as the leaders of the Panandita, Rsi and Pandita).

All Balinese customs are always related to PancaYadnya. The five Yadnyaare five holy sacrifices aimed at the God. All Balinese customs must always be preserved and preserved so as not to disappear.

\subsection{Obedience of the Balinese Community Overseas in the Special Region of Yogyakarta on Balinese Traditional Marriage Law}

For Balinese, marriage is an obligation that must be fulfilled. Marriage is closely related to the obligation to have descendants who will become heirs, continue purusaand atone for the sins of his ancestors, and carry out religious ceremonies, always astiti-bhakti (worship) to the ancestors who reside in sanggah or merajan. The principle of the purusa family system is in harmony with the family system in the Book of Manawadharmasastra, one of the Hindu 
religious books. The understanding that was engraved among the Balinese people in DIY inspired them to remain loyal to the customary law of Bali including the customary marriage law.

\section{a) Marriage is the Actualization of Darmaor the Duty of Life as Hindus}

As devout Hindus, Balinese wanderers are guided by the Vedic scriptures which guide human actions from birth to death, including the basis and guidance in carrying out marriage ceremonies. In harmony with the concept of Hinduism, overseas Balinese do not see marriage as a mere mundane (sekala) legal act, but also relates to the life of the unseen world (niskala). The concept of scale is a concept that cannot be separated from the life of religious Balinese people, who always maintain the harmonious relationship between the real world and the unseen world in every aspect of their lives.

Marriage which is carried out according to the guidance of Hinduism generally has three objectives:

a) Dharmasampati means that marriage is one of the dharma that must be carried out by Hindus in accordance with the teachings of CaturAshrama. Through marriage institutions, Balinese Hindus are given a way to carry out theirdarmafully.

b) Praja has the meaning of marriage aimed at giving birth to offspring who will continue the life in the world, so that marriage is very glorified because it can provide opportunities for descendantto melt away the sins of their ancestors.

c) Rati which means marriage is a legitimate way for the bride to feel the worldly blessings that are legally believed to be able to provide inner peace.

Marriage is essentially a yadnya or deed that gives the ancestors the opportunity to reincarnate in order to improve their karma (reincarnation). The existence of offspring is very urgent to free the ancestral spirits from the crater of hell and deliver it to nirvana, because the process of reincarnation through the kapurusaline.

\section{b) Marriage as an Instrument to Continue Kapurusa}

The adherence of Balinese migrants in DIY to the Balinese customary marriage law is also motivated by the patrilineal family system, so that carrying out marriages is a necessity in order to obtain offspring or sentana who continue the lineage. Their understanding of the Purusafamily system is in line with the customs prevailing in their ancestral lands, namely:

a) Family lines are tracked from male descendant. So far, Balinese in DIY still obey to the patrilineal family system (kapurusa or purusa). As a consequence, legally only those who come from one origin (wit, become kawitan) are considered a family. People who are included in this line are commonly called sakingpurusafamily. Whereas people from the mother's family which is commonly called a sakingpradanafamily is not considered as a family at all. The degree of one's relationship with relatives from the purusa line is far more important than the relationship with relatives on the part of the mother (sakingpradana).So important is the position of a boy in a family, so that to realize this principle, the Balinese wanderers try to be consistent to carry out ngantenkeluar. In this form of marriage, the wife is released from her legal relationship with her original family, then enters her husband's family. Children born from this marriage only have a family legal relationship with the family of the father's party (sakingpurusa), while they only have social and moral relations to the mother's family (sakingpradana). 
b) Swadharmaand swadikara are continued by male lineage.Referring to the principle of family line traced from this male offspring, a child is only responsible and continues the rights and obligations of the father alone. As a consequence of the principle of the emersion of rights and obligations based on the purusa line, the child born to a legal marriage always "belongs" or is considered as part of the purusa family. Heredity is a continuation of rights and obligations relating to family or related to society. Swadharma and swadikara in the family, for example, concerns the responsibility of caring for children or caring for parents in their old age, rights and obligations to inheritance, responsibility for care and continuity and worship of family worship places (sanggah / merajan), where ancestral spirits are buried. Community responsibilities involve responsibilities as members of a customary law community (banjar / pakraman village, subak, dadia), either in the form of ayahan (work obligations), pawedalan / papeson (a collection in the form of money or goods).

c) Reincarnation through the kapurusa line. The granting of primary status to boys (male) is related to Hindu religious beliefs about punarbawa, i.e boys can save their ancestral spirits from hell, and ancestral spirits can reincarnate through male offspring (reincarnation). Reincarnation occurs because the soul must bear the results of actions in his previous life. The process of reincarnation aims so that the soul can enjoy the results of his actions that have not been enjoyed. Besides being given the opportunity to enjoy, humans are also given the opportunity to improve their lives. It is believed that only by incarnating as a human, karma can be corrected to subha karma perfectly. The Balinese believe that reincarnation occurs by following the course of the kapurusa, and is not possible from predana families.

\subsection{Openness of Overseas Balinese Views in the Special Region of Yogyakarta Towards the Implementation of Balinese Traditional Marriage Law}

As explained in the previous section, that the Balinese Hindu community upholds their customary marriage. Marriage has spiritual and transcendental value. The Balinese Hindu community believes that marriage is a means for ancestors to be able to unite with God in purity, perfection, which is achieved through sukhinah marriage. In addition, the belief of the Balinese Hindu community that forgetting their ancestors will result in them not being saved, is also a "binding" of the Balinese Hindu community regarding their customs, especially related to marriage, wherever they are.

The intermingling of Balinese migrants in DIY however causes them to be more familiar with and accustomed to different customs, even diverse considering that DIY is a region with a heterogeneous population. This will be a challenge in maintaining customary law which is held firmly. As the opinion of Heryadi and Silvana (2013: 102) which states that someone who wanders will get various challenges in his new place, such as language, community attitudes, belief systems, and culture that are very different from the previous environment.

Among the Balinese (Hindu) people who wanders in DIY gradually there is a shift in understanding of the implementation of traditional marriages by Balinese migrants. There are several factors that cause these dynamics. The first factor is the intermingling process and the continuous interaction with the people living overseas. The Balinese migrants live in the midst of a variety of people in DIY. It also encourages the emergence of inter-ethnic marriages and interfaith marriages (with non-Hindus). This can not only have an impact on the survival of the Purusa, Swadikara and Swadharma which should be carried out by Sentana, but also to 
the Balinese inheritance system. Although Balinese Customary Law is not entirely derived from Hinduism, Hinduism is the source and spirit of Balinese Customary Law.

The second factor is the education of Balinese migrants. Balinese migrants who tend to have good education will have an open minded. They do not look at the concept of Balinese Customary Law with a narrow interpretation and think more contextually with the gender equality and human rights paradigm.

The third factor, namely the existence of government policies such as the Family Planning (KB) program which launched by the Government since the 1970s, has shown "results". The family planning program limits the birth of a child to each family, so the chances of having a son are reduced. It is entirely possible that a family does not have a son or only have a single daughter. Of course this has an impact on the marriage aspects of the Balinese Hindu community, including Balinese migrants. As is well known, boys have a very important role in the family, namely as a purusa. Indeed, there is a form of Nyentana marriage to provide a way out for families that only have daughters, providing that the prospective husband is willing to be predana and leave the family to enter the family's wife's status as male or purusa. What if hedoes not want to do nyentana? Thus at least, there are problems in Balinese traditional marriages, especially in wandering, which include the higher possibility of inter-ethnic, interreligions and inter castes marriages and alsothe lack of sons in a family.

Facing that situation, Balinese migrants in DIY have a relatively open-minded view. The fact that interactions with heterogeneous citizens are more likely to allow intermarriage of different ethnicities, religions, castes, is accepted as a necessity. But they still hold the principle that offspring (men in particular) will continue the "family temple", swadharma andswadikara. Therefore, even if the Balinese Hindus want to marry someone who has a different religion, they cannot leave Hinduism. When someone comes out of Hinduism, he will be ostracized by a large family. For people who convert from non-Hindus, there is a traditional ceremony to receive it from the birth ceremony to the cutting of teeth,

Regarding not having a son in the family or only having the only child of the prostitute, while the prospective bridegroom's family does not want to do a nyentana, Balinese migrants begin to accept the existence of a pada gelahangmarriage.Pada gelahang can be said to be a new form of marriage, in which the Balinese Hindu community previously only knew two types of marriage. As stated in the previous section, these two types of marriagesnamely ordinary marriages and nyentana or nyeburin marriages. In pada gelahangmarriage, both husbands and wives have a role as purusa in their respective families and carry double responsibilities and obligations (swadharma). They must continue the responsibilities of their respective families, both scale and noetic. Pada gelahangis considered to be able to save a family that does not have male offspring when the man also does not want to be sentana. Men don't want to be sentana because they are tied to their responsibilities to their own families.

The situation of equality between men and women as a purusain the pada gelahang shows that it is different from the traditional Balinese kinship system in general. As explained earlier that the Balinese adhere to a patrilineal family system called purusa. The existence of the balance of the position describes that pada gelahang marriage has characteristics of a parental system, no longer purely patrilineal. Even included in the status of their children who have the same rights and obligations, both in the father's family and mother's family. This is one of the dynamics that emerged in the implementation of marriage by indigenous Balinese, including Balinese migrants.

Padagelahang marriage is not seen as a negative form of marriage, instead it is considered as an alternative choice when ordinary marriages and nyentana marriages are not possible. The main principle that is maintained is the existence of offspring to continue family obligations 
by purusa. In the view of some wanderers, the term purusa is no longer meant only as a man and predana as a woman. Socially and culturally, in the past purusa (who actively expressed desires) were identified as men and predana (who accepted desires) as women. That's what causes purusameaning to be sexed. At present this kind of paradigm has shifted, so that the purusa can be held by women. This view also affects the matter of inheritance. Because in pada gelahang marriage the roles of men and women are equal, both girls and boys have the same inheritance rights.

At this time in the Balinese wanderers family in DIY began to implant the concept that the obligation to continue the ancestral purification mission is equally in boys and girls. Likewise for equal marriage (caste). In the past, marriages were expected to occur between men and women of the same level. That is because social stratification in the past is still firm. But now, some Balinese wandereres no longer see the problem of caste as a social class in a vertical, but horizontal context. These things are the influence of developments and changes that occur in the mindset of Balinese people, especially Balinese migrants, who are increasingly open.

Another important principle in Balinese traditional marriages is the belief that the entire set of rituals in the implementation of Balinese traditional marriages must be carried out in full will bring the blessing of marriage. This is related to the beliefs of the Balinese including Balinese wanderers that there will be 3 (three) witnesses in marriage, namely humans, Gods of witnesses, and nature of witnesses.

Adherence to Balinese traditional marriages is a necessity that must be continually preserved to maintain their customs. On the other hand, denying the change is also not possible. The dynamics in the implementation of Balinese marriage by Balinese wanderers will continue to occur. The role of the family (parents) in continuing and maintaining Balinese customs is very significant.

\section{Conclusion}

As a form of darma as Hindus who are obliged to provide a place for their ancestors to reincarnate through the kapurusa line, the Balinese wanderers continue to obey Balinese traditional marriage laws. Traditionally, traditional marriages aimed at continuing the male lineage (kapurusa), are ngantenkeluar (women enter to husband's family) and nyentanamarriage (husband played as predana and entered to wife's family). In subsequent developments, there is a dynamic understanding of Balinese customary marriage law, especially among wanderers communities, in which there are Balinese wanderers who interpret customary marriage law contextually Intermingling with people in wandering area and other factors encourages the views of migrants to be more open, such as accepting pada gelahang marriage to accommodate changes while maintaining the main principles of Balinese customary marriage law.

\section{References}

[1] Adnyani, Ni Ketut Sari. (2016). Bentuk Perkawinan Matriarki Pada masyarakat Hindu bali Ditinjau dari Perspektif Hukum dat dan Kesetaraan Gender. Jurnal ilmu Sosial dan Humaniora. Vol. 5. No.1. April 2016 
[2] Dyatmikawati, Putu (2015) Kewajiban pada perkawinan "Pada Gelahang"dalam perspektif hukum adat Bali . Jurnal Kajian Bali Vol. 05, Nomor 02, Oktober 2015

[3] Faisal, Sanapiah. (1990). Metode Penelitian Kualitatif. Malang: Universtas Brawijaya.

[4] Heryadi, H. \& Silvana, H. (2013). Komunikasi Antarbudaya dalam Masyarakat Multikultur (Studi tentang Adaptasi Masyarakat Migran Sunda Di Desa Imigran Permu Kecamatan Kepahiang Provinsi Bengkulu). Jurnal Kajian Komunikasi,(1-1) 95-108.

[5] Hemmalini, Kadek \& Suhardi, Untung. (2015). Dinamika Perkawinan Adat Bali. Status dan kedudukan Anak Sentana Rajeg Menurut Hukum Adat Dan Hukum Hindu. Jurnal Dharmasmarti. Vol. XIII. No. 26. Oktober 2015.

[6] Irianto, Sulistyowati. (2003). Pluralisme Hukum dan Masyarakat SaatKrisis. DalamMasinambow, E.K.M (Ed).2003. Hukum dan KemajemukanBudaya. Jakarta: Yayasan Obor Indonesia

[7] Naim, Mochtar. 2012. Merantau : Pola Migrasi Suku Minangkabau. Jakarta : PT Raja Grafindo Persada

[8] Padilla, A. M., \& Perez, W. (2003). Acculturation, social identity, and social cognition: A new perspective. Hispanic Journal of Behavioral Sciences, 25(1), 35-55

[9] Sudantra, I Ketut dan Dharma Laksana, I Gusti Ngurah. (2017). Pluralisme hukum yang berlaku dalam perkawinan umat Hindu Bali. Makalah dalam Seminar Nasional Sains dan Teknolgi IV

[10] Sudantra, I Ketut. (2010) . Hukum perkawinan bagi umat Hindu di Bali. Makalah dalam semiloka "perkawinan bagi umat Hindu Bali.

[11] Suwitra Pradnya, Ida Bhegawan Istri. (2017), Purusha dan Predhana dalam Agama Hindu dan Hukum Adat Bali, Pustaka Ekspresi

[12] Windia, P. Wayan dan Sudantra, Ketut (2006) Pengantar Hukum Adat Bali. Lembaga Dokumentasi dan Publikasi Fak Hukum Universitas Udayana,

[13] Wayan P. Windia.(2008). Menyoal Awig-awig Eksistensi Hukum Adat dan desa di Bali. Lembaga Dokumentasi dan Publikasi Fak Hukum Universitas Udayana 